の場合 $2 / 11(18 \%) ， 0 / 9(0 \%) ， 9 / 9(100 \%)$ であ， 同様に Type III による固定法を用いた場合の聴力改 善率が最も良好であった. 聴力改善不成功 24 耳の内訳 は, 鼓膜壊死……5 , 鼓膜大穿孔 $\cdots \cdots . . .4$, 鼓膜小穿孔

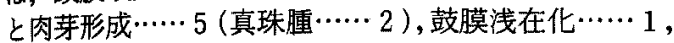
耳小骨離断……2, 耳小骨固着……1, 缒骨突出…… 1,鼓膜の俩凹とツチ骨柄の前方偏位…… 鼓室形成術は乾燥耳に対して行うのが望ましいが, い
ずれにせよ同種鼓膜を使用する場合, 確実な鼓膜の固 定法（すなわち，Type IIIによる方法）が上述のごと き種々の鼓膜, 耳小骨の形態的変化を防止するのに重 要な役割を演じ，ひいては聴力改善につながるといえ る. 質問 山本悦生 (神戸中央市民). 同種鼓膜, 耳小骨移植の詳細を。応答 鼓膜の移植は伝音連 鎖の再建のための耳小骨移植を組み合わせて行ってい る. Myringotomyのためには使用していない。

\title{
100. 中耳コレステリン肉芽腫について
}

\section{森弘・岩永迪孝・稲井英樹・酒井豊彦（北野病院）}

目的慢性中耳炎手術例の中には，コレステリン肉 芽堙が多数混入することは周知のことである。私ども は，1977年より1986年までの10年間に慢性中耳炎手術 を1568例に行った。 その中で, 648 耳に術創より採取し た病的肉芽を普通光学顥微鏡により検查した. その結 果, コレステリン肉芽腫合併を122耳に認めた. その病 態については，耳鼻臨床81巻に原著として発表した。 記載内容の中で，もつとも問題点としたのは，聴力が 想像以上に不良なことである。すなわち，術前聴力が 一部スケールアウトおよびろうは 12 耳 $(10 \%)$, 術後聴 力が一部スケールアウトおよびろうが20耳（17\%）の 多数に達したのである. 中耳炎手術に際して, 術後聴 力が不良となることは極力回避したいのである、この 問題点を解決するためには, 各症例の管理, 手術様式 などに一段の工夫を要するといえる。そこで，もっと も新しい資料として，1987年から1988年の，最近 2 年 間の, 慢性中耳炎手術417耳中コレステリン肉芽腫合併 と病理組織学的に判定した 49 耳の病態を再度分析し た。そして, 過去10年間の結果と比較検討した結果, 若干の新知見を認めたので発表した。

結果 1) 症例数: 417 耳中 49 耳 $12 \%$ で，過去の集計 1568耳中 122 耳 $7.8 \%$ 上り高頻度の発見率といえる，2） 年齢分布 : $20 \sim 49$ 歳が417耳中 31 耳 $63 \%$ で, 過去の集計 $122 耳$ 耳 83 耳 $68 \%$ と大差なく, 依然として, 同様の年代 に本症が多い.3）真珠腫の合併率：49耳中 31 耳 $63 \%$ で, 前回は122耳中78耳64\%であるので, ほほ同率とい
える.4）顔面神経麻痺切上び顔面神経管病変：49耳中 24 耳 $49 \%$ あるるが, 前回の122耳中36耳 $30 \%$ と比較する と, やや増加傾向を認める．5) 強度聴力損失(一部ス ケールアウト,ろう)：徒前49耳中 5 耳 $10 \%$ 加ら術後も 5 耳で増加していない，既述のごとく，前回は，122耳 中12耳10\%より術後20耳17\%に増加している.6) 手術 様式：段階手術が49耳中23耳約半数に達しているのが 特徴である.前回は，段階手術が応用されたのは122耳 中 $12 耳 10 \%$ に過ぎなかった。

むすU゙ 1) 慢性中耳炎手術例には,中耳炎の病像が 重症化するコンステリン肉芽腫合併症が多数混在す る.2）症例の管理として, 術前より内耳機能保護薬な どの投与の他，段階手術の応用が，術後聴力賣失がき わめて不良となることを防止するために有用と考えら れる.3）顔面神経病変合併症の増加傾向に注意した い. 質問 滝本 勲(爱知医大). 術後聴力が悪く なるのはすべて鼓室にコレステリン肉芽があった例 か.また,この肉芽が何故内耳にそれ程悪い影響を与え ると考えるか. 応答 コ肉芽腫をもっとも多く認 めるのは，乳突部より採取した病的肉芽である.コ肉 芽嗹が顔神管や内耳人の強い障害を与えるのは，単な る真珠腫などとは異なる作用機序があると思う。

質問 山本悦生 (神戸中央市民)。病理検查以外に, 術 中にコレステリン肉芽腫と肉眼的に診断するポイント 注. 応答 肉芽腫を術中, 肉眼的に判定, 分析す ることはきわめて困難である。

\section{1．鼓室硬化症について \\ 一臨床像を中心に一}

磯野道夫 ·山本悦生 - 大村正樹 - 広野喜信 - 水上千佳司・竹林恵子（神戸市立中央市民）

慢性中耳炎の一亜型として考えられてきた鼓室硬化 症は，日常臨床において，どのように治療されている のであろうか. 成因的にも不明な点が多く，臨床的に も診断, 治療法共にいまだ確立された方法はない。演 者らは,この鼓室硬化症を昭和 62 年 5 月以来検討して
おり，57耳に鼓室形成術を行っている．本症を耳小骨 周囲に石灰化病変を伴いかつその可動性が障害されて いるものと定義し，その臨床像についてまとめてみた。 年㢼, 性差では30歳代〜50歳代の女性に多い傾向が みられた。術前診断として有用なものとして次のもの 